\title{
ANALISIS KONSTRUKSI DAN HASIL TANGKAPAN JARING INSANG PERMUKAAN DI PERAIRAN KABUPATEN MAROS PROVINSI SULAWESI SELATAN
}

\section{ANAL YSIS ON CONSTRUCTION AND FISH CATCH OF SURFACE GILL NETS IN MAROS REGENCY WATERS, SOUTH SULAWESI PROVINCE}

\author{
Dermawati ${ }^{1}{ }^{\star}$, Mahfud Palo $^{1}$, Najamuddin $^{1}$ \\ 1) Program Studi Pemanfaatan Sumberdaya Perikanan Fakultas Ilmu Kelautan dan Periknan Universitas \\ Hasanuddin
}

Diterima: 21 Februari 2019; Disetujui: 12 Maret 2019

\begin{abstract}
ABSTRAK
Penelitian ini bertujuan untuk mendeskripsikan konstruksi jaring insang permukaan dan menganalisis hasil tangkapan jaring insang permukaan berdasarkan konstruksi jaring insang permukaan. Penelitian ini dilaksanakan pada bulan April sampai Juni 2018 yang bertempat di Desa Pajukukang, Kecamatan Bontoa, Kabupaten Maros. Metode penelitian yang digunakan adalah metode studi kasus, pengambilan data yang dilakukan dengan mengikuti operasi penangkapan selama 30 trip. Pengumpulan data meliputi pengukuran alat tangkap, ukuran panjang, jenis dan total hasil tangkapan. Data analisis yang digunakan yaitu perhitungan dimensi alat tangkap. Hasil penelitian dengan ukuran mata jaring 2,5 inci $(6,35 \mathrm{~cm})$ menangkap ikan kwee dengan panjang 13,5-19,8 $\mathrm{cm}$, ikan senangin dengan panjang 16,2-22,7 cm, ikan bandeng dengan panjang 18,2-23,5 cm dan ikan Bandeng lelaki 19,5-27,6 cm dengan shortening atas 58,7 \% dan shortening bawah 55,67 \% menunjukkan bahwa ikan terjerat dan terbelit. Daya apung pelampung $0,12 \mathrm{~g}$, total daya apung pelampung 424,72 $\mathrm{g}$, daya apung tali ris atas $7,17 \mathrm{~g} / \mathrm{m}$, daya apung tali ris bawah $11,75 \mathrm{~g} / \mathrm{m}$. Daya tenggelam pemberat $7,98 \mathrm{~g}$ dan daya tenggelam jaring 36,11 . Panjang jaring $72,64 \mathrm{~m}$, luas jaring $38,95 \mathrm{~m}^{2}$. Total hasil tangkapan terbanyak berada pada trip ke -15 dan 17 dengan jumlah total hasil tangkapan sebanyak 42 ekor, sedangakan pada hasil tangkapan sedikit berada pada trip ke- 3 dengan jumlah hasil tangkapan sebanyak 5 ekor. Hasil tangkapan dominan yaitu ikan kwee (Carangoides coeruleopinnatus), ikan Senangin (Eleutheronema tetradacttylum), ikan bandeng (Chanos chanos) dan ikan Bandeng lelaki (Elops hawaiensis).
\end{abstract}

Kata kunci: Aspek teknis, Hasil tangkapan, Jaring insang permukaan

\begin{abstract}
The purpose of this research was to describe the construction of surface gill nets and analyze the fish catches of surface gill nets based on the construction ofsurface gill nets. The research was conducted from April to June 2018 in Pajukukang Village, Bontoa District, Maros Regency. The research method used is a case study method, data retrieval is done by following fishing operations for 30 trips. Data collection includes measurement of fishing gear, length, type and totality catchtable. The analysis data used is the calculation of the dimensions of
\end{abstract}


fishing gear. The results of the study with the size of 2.5 inch $(6.35 \mathrm{~cm})$ mesh caught Coastal Trevally with a length of $13.5-19.8 \mathrm{~cm}$, Fourfinger treadfind with a length of $16.2-22.7 \mathrm{~cm}$, milkfish with a length of $18.2-23.5 \mathrm{~cm}$ and hawaiian ladyfish $19.5-27.6 \mathrm{~cm}$ with upper shortening of $58.7 \%$ and lower shortening of $55.67 \%$ indicating that fish are entangled. Float buoyancy was $0.12 \mathrm{~g}$ each and the total buoyancy $424.72 \mathrm{~g}$, the head rope buoyancy $7.17 \mathrm{~g} / \mathrm{m}$, the ground rope buoyancy $11.75 \mathrm{~g} / \mathrm{m}$. The sinker sinking force were $7.98 \mathrm{~g}$ and the net sinking force was $36.11 \mathrm{~g}$. The net length of $72.64 \mathrm{~m}$, net area of $38.95 \mathrm{~m}^{2}$. The total catches are mostly in the 15th and 17th trip with a total catch of 42 fish, while the catchetable are slightly on the third trip with the catch amounting to 5 fish. The dominant catches were coastal Trevally (Carangoides coeruleopinnatus), Fourfinger treadfind (Eleutheronema tetradactty/um), milkfish (Chanos chanos) and hawaiian ladyfish (Elops hawaiensis).

Keywords: Technical aspects, fish catch, surface gill nets

Contact person : : Dermawati

E-Mail :dermawhati@gmail.com

\section{PENDAHULUAN}

Kabupaten Maros terletak dibagian baratSulawesi Selatan antara $40^{\circ} 45^{\prime}-50^{\circ} 07^{\prime}$ Lintang Selatan dan $109^{\circ} 20^{\prime}$ - 129 $12^{\prime}$ Bujur Timur. Sebelah Utara berbatasan dengan Kabupaten Pangkep, sebelah Selatan berbatasan dengan Kota Makassar dan Kabupaten Gowa, sebelah Timur berbatasan dengan Kabupaten Bone, dan sebelah Barat berbatasan dengan Selat Makassar. Kabupaten Maros sebagai daerah pesisir pantai dan laut memiliki potensi pengembangan perikanan darat dan laut yang cukup besar. Dimana untuk saat ini jenis budidaya perikanan yang diusahakan adalah laut, sungai, tambak dan kolam. Jenis produksi yang dihasilkan terbanyak saat ini bersumber dari laut dengan produksi tahun 2008 mencapai 20.197 .93 ton (DKP Maros, 2015).
Jaring insang permukaan surface gill net salah satu alat tangkap yang sangat selektif dan mudah dikontrol penggunaannya, disamping itu jaring insang permukaan dapat dipakai dengan menggunakan perahu sederhana tanpa menggunakan perahu motor. Ini merupakan suatu hal yang penting untuk negara yang sedang berkembang, dimana modal nelayan biasanya masih kecil (Ayodhyoa, 1981).

Penentuan konstruksi dalam sebuah alat tangkap sangat di pengaruhi terhadap kondisi perairan yang terdapat di lokasi penelitian. Kondisi perairan yang dimaksud adalah kecepatan arus dan pasang surut air laut. Kecepatan arus disebabkan oleh perbedaan densitas massa air laut, tiupan angin terus menerus diatas permukaan laut dan pasang surut terutama di daerah pantai. Pasang surut juga penting diketahui untuk 
menentukan penempatan alat tangkap yang akan dioperasikan sehingga tidak terjadi penarikan tali yang terlalu kuat ataupun terjadi kelonggaran.

Konstruksi berhubungan dengan tata letak ataupun penyusunan. Sebelum dilakukan penyusunan atau peletakan komponen, diperlukan pengetahuan dasar mengenai target tangkapan seperti halnya ukuran dan pola gerak sehingga alat tangkap tersebut dapat berhasil saat dioperasikan di perairan.

Pada beberapa lokasi penangkapan di perairan Indonesia, terdapat berbagai macam kontruksi gill net permukaan dan terhadap hasil tangkapan yang beranekaragam. Pada penelitian yang telah dilakukan di Maluku Teluk Kayeli Kabupaten Buru dengan konstruksi jaring yang digunakan adalah benang dari bahan polyamide no. 25, mata jaring berukuran 1,5, 1,75 dan 2.0 inci. Hasil tangkapannya didominasi oleh ikan layang Decapterus macarelus dengan komposisi berkisar ukuran ikan yang tertangkap dengan jaring insang permukaan ukuran mata 1,75 inci mulai dari panjang standar 155 mm- 295 mm dan jaring berukuran mata 2,0 inci mulai dari panjang standar 185 mm - 295 mm, sedangkan jaring berukuran mata 1,5 inci mulai dari panjang standar 135 mm - 245 mm. Hasil uji beda menunjukkan bahwa jaring berukuran mata 1,75 inci lebih efisien dari jaring berukuran mata 1,5 inci dan 2,0 inci (Tawari, 2013).

Tertangkapnya ikan-ikan dengan gill net ialah dengan cara ikan-ikan tersebut terjerat gilled pada mata jaring ataupun terbelit entangled pada tubuh jaring. Pada umumnya ikan-ikan yang yang menjadi tujuan penangkapan ialah jenis ikan yang horisontal migration dan vertikal migration-nya tidak seberapa aktif. Dengan perkataan lain migration dari ikan-ikan tersebut terbatas pada suatu range layer-depth tertentu. Berdasarkan depth dari swimming layer ini lebar jaring ditentukan.

Untuk meningkatkan produksi perikanan laut diperlukan pengelolaan dan pemanfaatan sumberdaya yang baik. Salah satu bentuk pemanfaatan sumberdaya adalah penangkapan ikan yang ditunjang oleh unit alat tangkap yang digunakan dan keterampilan serta pengetahuan tentang ikan itu sendiri.

$$
\text { Pada penelitian ini akan mengkaji }
$$
mengenai konstruksi dan hasil tangkapan. Analisis konstruksi untuk mengetahui konstruksi dan metode pengoprasian jaring insang permukaan surface gill net serta hasil tangkapan dari penggunaan jaring insang permukaan yang memberikan konstribusi yang 
besar bagi nelayan di perairan Kabupaten Maros. Untuk itu perlu dilalakukan penelitian tentang analisis kontruksi dan hasil tangkapan jaring insang permukaan di perairan Kecamatan Bontoa Kabupaten Maros.

Adapun tujuan yang diharapkan dalam pelaksanaan penelitian ini yakni sebagai berikut:

1. Mendeskripsikan desain dan konstruksi jaring insang permukaan yang dioperasikan di perairan Kabupaten Maros

2. Mendeskripsiskan ukuran hasil tangkapan jaring insang permukaan
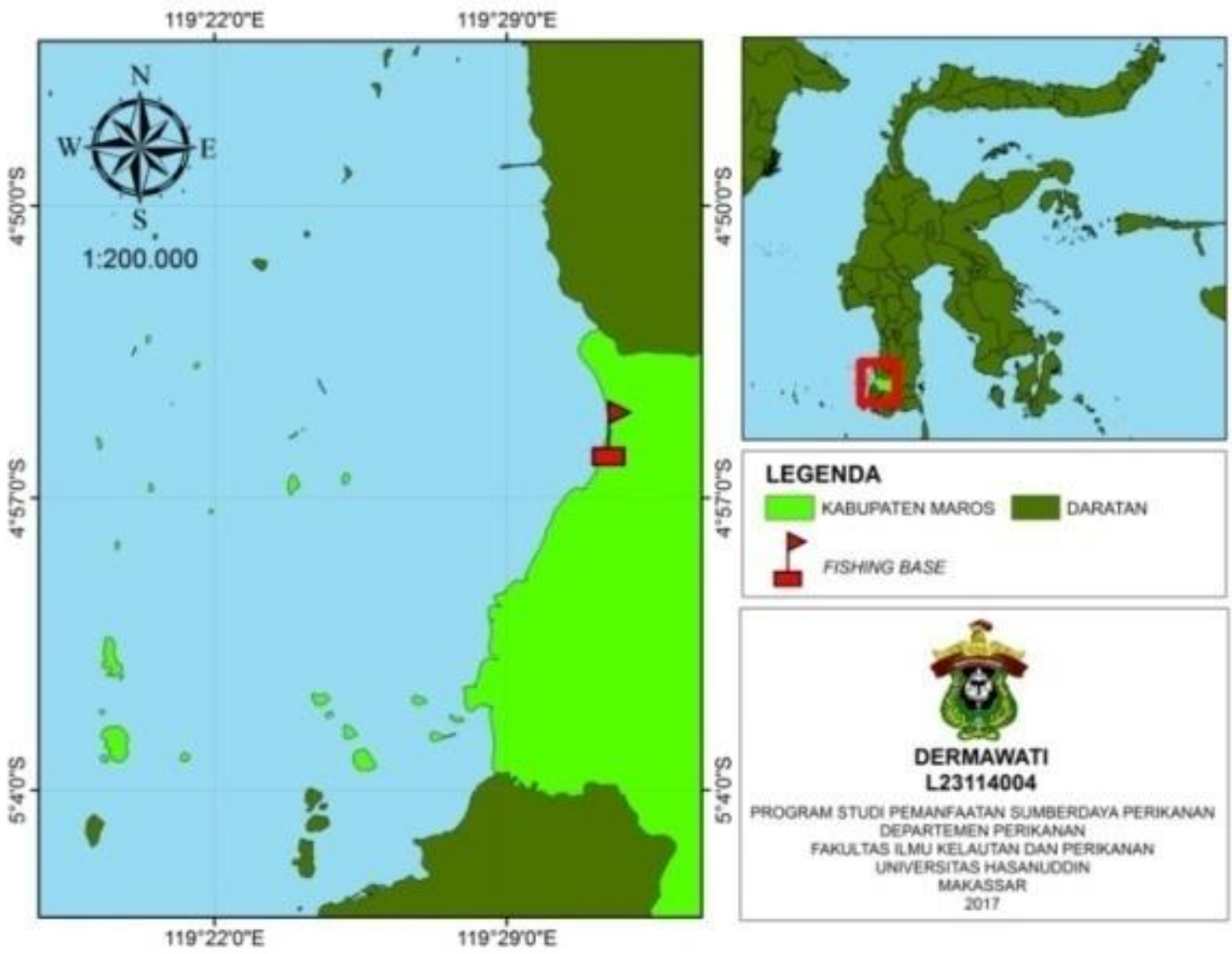

Sedangkan kegunaan dari penelitian ini sebagai bahan informasi bagi masyarakat nelayan, pemerintah daerah maupun pihak yang terkait dengan bidang perikanan dalam usaha peningkatan sumberdaya perikanan tangkap di Kabupaten Maros.

\section{BAHAN DAN METODE}

\section{Waktu dan Tempat}

Penelitan ini mIulai dilaksanakan pada bulan April-Juni 2018 yang bertempat di Desa Pajukukang, Kecamatan Bontoa, Kabupaten Maros. 


\section{Alat dan Bahan}

Adapun alat dan bahan yang digunakan dalam penelitian ini dapat dilihat pada Tabel 1. Tabel 1. Alat dan bahan yang digunakan dalam penelitian

\begin{tabular}{lll}
\hline No & Nama Alat dan Bahan & \multicolumn{1}{c}{ Fiungsi } \\
\hline 1.. & Rol meter & $\begin{array}{l}\text { Untuk mengukur alat dan } \\
\text { kapal penangkapan }\end{array}$ \\
2. & Penggaris & $\begin{array}{l}\text { Untuk mengukur mata } \\
\text { jaring dan mengukur ikan }\end{array}$ \\
3. Timbangan & $\begin{array}{l}\text { Untuk menimbang hasil } \\
\text { tangkapan }\end{array}$ \\
4. Kamera & $\begin{array}{l}\text { Untuk dokumentasi } \\
\text { 5. Alat tulis menulis }\end{array}$ & $\begin{array}{l}\text { Untuk mencatat data } \\
\text { dilapangan }\end{array}$ \\
6. GPS (Global Positioning & $\begin{array}{l}\text { Untuk } \\
\text { koordinat } \\
\text { penangkapan } \\
\text { Untuk pengumpulan data }\end{array}$ \\
7. $\quad$ Kuisioner & Perangkat Komputer & Untuk mengolah data
\end{tabular}

\section{Metode Penelitian}

Metode yang digunakan dalam penelitian ini adalah penelitian studi kasus, yaitu mempelajari dan menganalisis satu unit jaring insang permukaan yang ada pada lokasi penelitian. Pengumpulan data yang dilakukan dengan menggunakan data primer yang di peroleh dari hasil wawancara langsung dengan nelayan yang berkaitan dengan alat tangkap jaring insang permukaan dan melakukan observasi langsung kelapangan dengan mengikuti operasi penangkapan jaring insang permukaan sebanyak 30 trip penangkapan.

Adapun teknik pengambilan data adalah sebagai berikut:

1. Data hasil tangkapan diperoleh dengan cara menimbang dan mengukur ikan berdasarkan jenisnya pada setiap trip penangkapan.

2. Mengambil data posisi daerah penangkapan jaring insang permukaan dengan menggunakan GPS (Global Position System).

\section{Parameter Pengamatan}

Parameter yang diamati yaitu:

1. Dimensi alat tangkap (bahan dan konstruksi alat tangkap)

2. Teknik dan waktu pengoperasian alat tangkap

3. Berat dan panjang cagak hasil tangkapan dominan ikan yang di tangkap

4. Jenis dan total hasil tangkapan

5. Jarak dari fishing base ke fishing ground

\section{Analisis Data}

Analisis data merupakan langkah terakhir dari proses data yang dikumpulkan dari atau tentang responden. Selanjutnya melakukan 
kegiatan analisa hasil-hasil yang telah diperoleh:

\section{Analisis teknis}

Analisis data yang digunakan untuk mencapai tujuan penelitian ini adalah

a. Teknik pengoperasian

Teknik pengoprasian alat tangkap dianalisa secara deskriptif dari tahapan persiapan sampai pada proses pengoperasian dan pengambilan hasil tangkapan.

b. Alat tangkap

Perhitungan dimensi alat tangkap (Sadhori, 1984).

a) Shortening

$$
\mathrm{S}(\%)=\frac{\mathrm{L}_{-\mathrm{I}}}{\mathrm{L}} \boldsymbol{x} 100 \%
$$

Dimana:

$$
\begin{array}{ll}
\mathrm{S} & =\text { Shortening } \\
\mathrm{L} & =\text { Panjang jaring kearah horizontal }(\mathrm{m}) \\
\mathrm{I} & =\text { Panjang tali ris }(\mathrm{m})
\end{array}
$$

b) Tinggi jaring

Tinggi jaring dapat dilakukan dengan persamaan (Najamuddin, 2009). yaitu:

$$
\mathrm{d}=\mathrm{m} \times \mathrm{n} \sqrt{2 s-s^{2}}
$$

Dimana:

$\mathrm{d}=$ mesh depth, tinggi jaring kearah dalam (tinggi jaring setelah jaring dibuat alat tangkap) (m) $\mathrm{m}=$ ukuran mata jaring/mesh size $(\mathrm{cm})$

$\mathrm{n}=$ jumlah mata jaring kedalam (mata)

$\mathrm{s}=$ Shortening (\%)

c) Luas jaring

Perhitungan luas jaring dengan persamaan yaitu (Prado \& Dremiere, 1991).

$$
S=E \times \sqrt{1-E^{2}} \times L \times H \times a^{2}
$$

Dimana:

$\mathrm{S}=$ Luas jaring $\left(\mathrm{m}^{2}\right)$ liput permukaan jaring $\left(\mathrm{m}^{2}\right)$

$E=$ Hanging ratio (horizontal/mendatar)

$\mathrm{L}=$ Jumlah mata jaring horizontal

$\mathrm{H}=$ Jumla mata jaring vertical

$a^{2}=$ (ukuran mata jaring tegang dalam meter) persegi

d) Daya apung

- Daya apung pelampung

Perhitungan daya apung pelampung dengan persamaan yaitu (Nomura, 1978).

$$
\mathbf{B}=\mathbf{W}\left(\frac{1}{\rho}-\mathbf{1}\right)
$$

Dimana:

$\mathrm{B}=$ Daya apung pelampung $(\mathrm{g})$

$\mathrm{W}=$ Massa pelampung

$\rho=$ Massa jenis pelampung

- Daya apung tali

Perhitungan daya apung tali dengan persamaan yaitu (Nomura, 1978).

$$
B=W\left(\frac{1}{\rho}-1\right)
$$

Dimana:

$$
\begin{aligned}
\mathrm{B} & =\text { Daya apung tali }(\mathrm{g} / \mathrm{m}) \\
\mathrm{W} & =\text { Massa tali } \\
\rho & =\text { Massa jenis tali }
\end{aligned}
$$


e) Daya tenggelam

- Daya tenggelam pemberat

Perhitungan daya tenggelam pemberat dengan persamaan yaitu (Nomura, 1978).

$$
S=W\left(1-\frac{1}{p}\right)
$$

Dimana:

$$
\begin{aligned}
& \mathrm{S}=\text { Daya tenggelam pemberat }(\mathrm{kg}) \\
& \mathrm{W}=\text { Massa pemberat } \\
& \rho=\text { Massa jenis pemberat }
\end{aligned}
$$

- Daya tenggelam jaring

Perhitungan daya tenggelam jaring pemberat dengan persamaan yaitu (Nomura, 1978).

$$
S=W\left(1-\frac{1}{p}\right)
$$

Dimana:

$$
\begin{aligned}
& \mathrm{S}=\text { Daya tenggelam jaring }(\mathrm{kg}) \\
& \mathrm{W}=\text { Massa jaring } \\
& \rho=\text { Massa jenis jaring }
\end{aligned}
$$

- Total Daya Apung (Total Bouyancy)

Perhitungan total daya apung total

Bouyancy dengan persamaan yaitu

(Nomura, 1978).

$$
\mathrm{EB}=\frac{T B-T S}{T B} \times 100 \%
$$

Dimana:

$$
\begin{aligned}
& \mathrm{EB}=\text { Ekstra bouyancy } \\
& \mathrm{TB}=\text { Total bouyancy } \\
& \mathrm{TS}=\text { Total singking }
\end{aligned}
$$

\section{Komposisi Hasil Tangkapan}

Komposisi jenis hasil tangkapan dihitung berdasarkan setiap trip dengan menggunakan rumus (Odum, 1996).

$$
\mathbf{p}=\frac{\mathbf{n i}}{\mathbf{N}} \mathbf{X 1 0 0} \%
$$

Dimana:

$\mathrm{P}$ : presentasi relatif hasil tangkapan (\%)

ni : jumlah hasil tangkapan spesies (i) ( $\mathrm{kg}$ )

$\mathrm{N}$ : jumlah seluruh jenis ikan yang tertangkap $(\mathrm{kg})$

\section{Ukuran hasil tangkapan yang dominan}

Untuk hasil tangkapan yang diamati adalah mengukur berat dan panjang masingmasing jenis ikan yang tertangkap dengan menggunakan alat tangkap jaring insang permukaan.

Pengukuran panjang ikan yang dihitung adalah panjang cagak, hasil tangkapan yang dominan diukur dengan menggunakan mistar, pengukuran panjang ikan yang diukur dari ujung kepala yang terdepan sampai ujung bagian luar lekukan cabang sirip ekor.

\section{HASIL DAN PEMBAHASAN}

\section{Gambaran Umum Lokasi Penelitian}

Penelitian ini dilakukan di Desa Pajukukang Kecamatan Bontoa Kabupaten Maros nelayan dengan menggunakan jaring insang permukaan. Penelitian ini tidak hanya mempunyai 1 jenis alat tangkap yang biasa di 
operasikan akan tetapi 2 sampai 3 jenis alat tangkap. Bagi masyarakat yang tak memiliki kapal mereka berprofesi sebagai ABK kapal penangkapan ikan, misalnya kapal purse seine yang dioperasikan diluar perairan Maros dan sebagian berprofesi sebagai petani untuk memenuhi kebutuhan sehari hari. Terdapat beberapa alat tangkap ikan yang digunakan oleh nelayan di pemukiman tersebut diantaranya purse seine, jaring insang permukaan, jaring insang dasar, jaring kepiting, bubu lipat, dan waring udang.

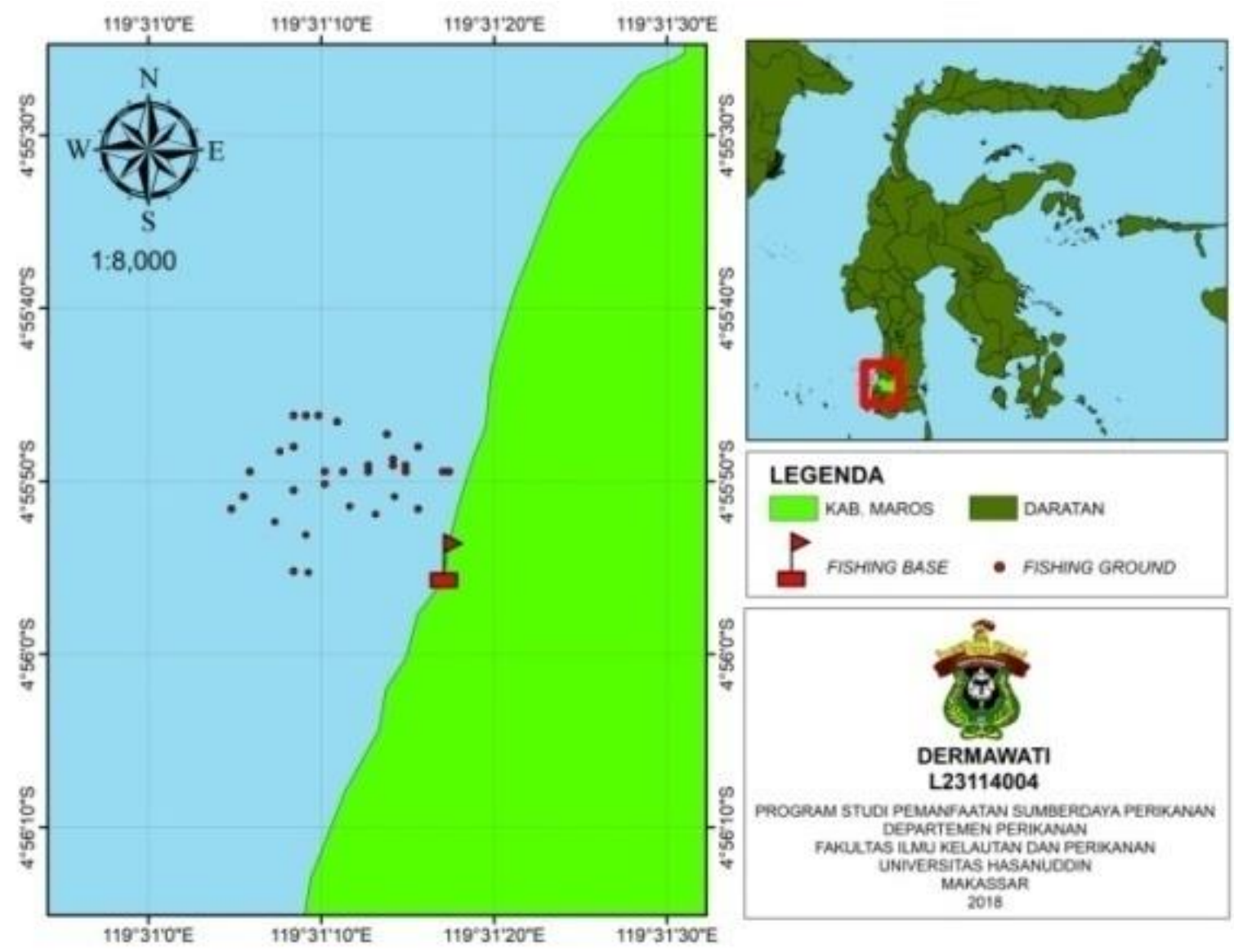

Gambar 2. Daerah penangkapan jaring insang permukaan di perairan Kabupaten Maros

Deskripsi Jaring Insang Permukaan

\section{Badan Jaring}

Jaring insang permukaan yang digunakan oleh nelayan di Desa Pajukukang, Kecamatan Bontoa, Kabupaten Maros, Provinsi Sulawesi Selatan menggunakan jaring yang terbuat dari bahan monofilament dengan nomor benang 40 yang berwarna bening. Badan jaring dihubungkan langsung dengan tali ris bawah dan tali ris atas. Adapun mesh size yang digunakan untuk jaring insang permukaan ukuran 2,5 inci $(6,35 \mathrm{~cm})$. Jumlah 
mata horizontal 1144 mata dan jumlah mata vertikal 22 mata. Panjang tali ris atas jaring insang permukaan yaitu $30 \mathrm{~m}$ dan panjang tali ris bawah yaitu $32,20 \mathrm{~m}$, pada setiap pengoprasian nelayan menggunakan 9 piece jaring yang panjangnya $300 \mathrm{~m}$ dan kedalaman jaring 1, $27 \mathrm{~m}$. Hasil pengukuran tersebut membuktikan bahwa pada bagian tali ris bawah lebih panjang dibandingkan dengan panjang tali ris atas jaring. Hal tersebut dipengaruhi oleh besarnya nilai shortening pada bagian atas sebesar 58,7 \% lebih besar dibandingkan dengan nilai shortening pada bagian bawah sebesar 55,67 \%. Hal ini sesuai dengan pernyataan Najamuddin (2012) shortening yang diberikan pada jaring bagian atas dibuat lebih besar dibandingkan pada jaring bagian bawah, sehingga jaring bagian bawah ukurannya lebih panjang dibandingkan bagian atas dengan tujuan agar posisi jaring sewaktu dioperasikan dapat terentang dengan baik di dalam perairan. Pemberat yang digunakan yaitu kulit kerang sedangkan pelampung adalah terbuat dari bahan karet sandal.

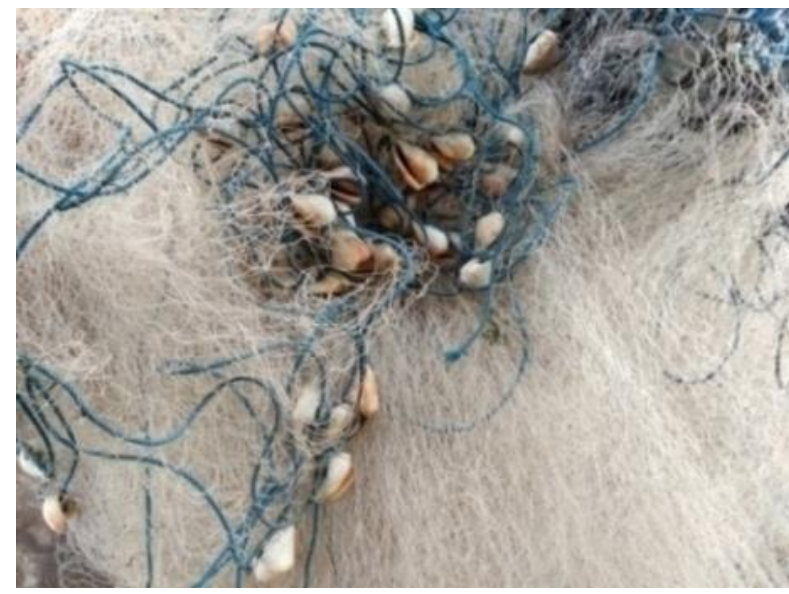

Gambar 3. Jaring insang permukaan yang beroperasi di perairan Kabupaten Maros

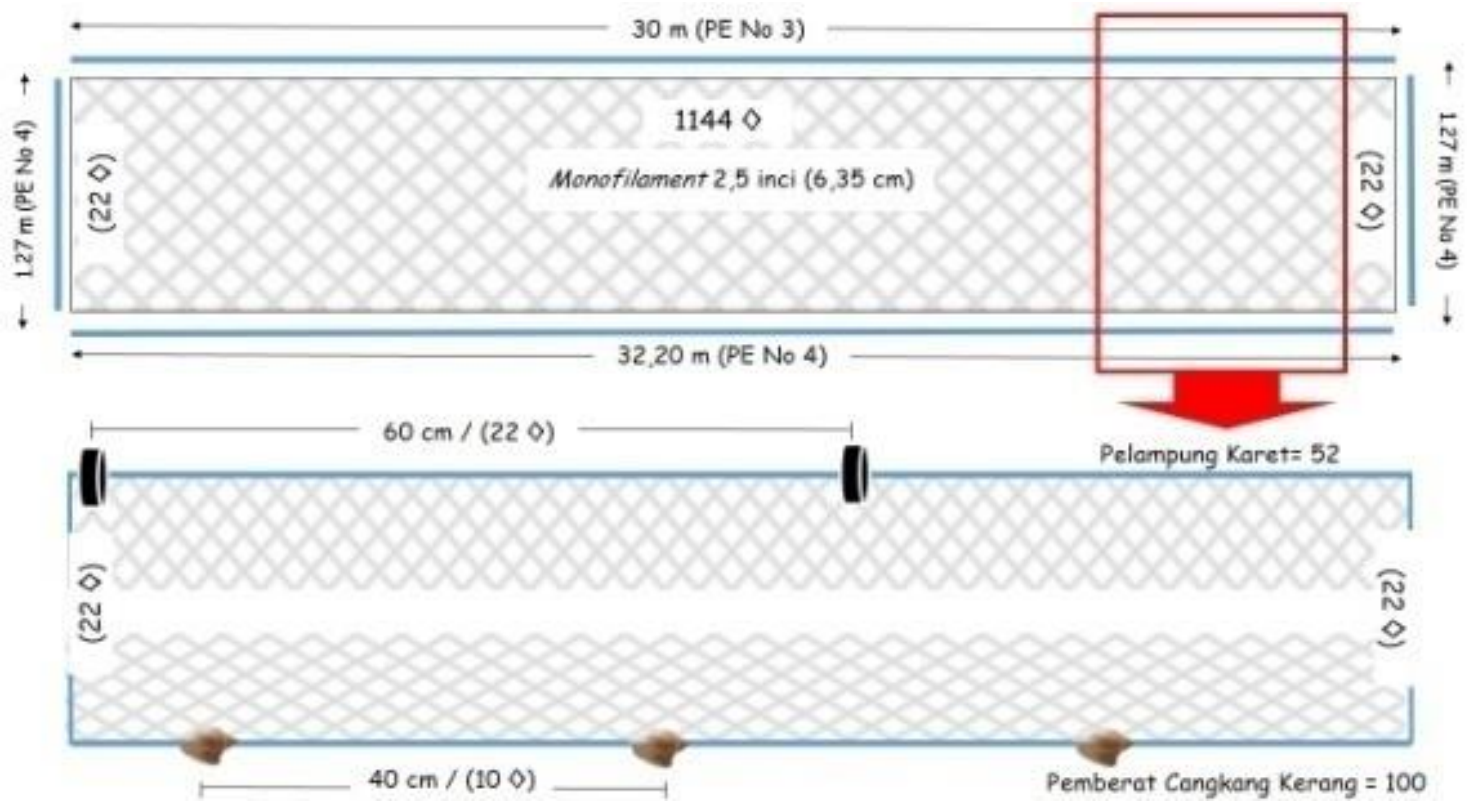

Gambar 4. Sketsa jaring insang permukaan di perairan Kabupaten Maros 


\section{Kapal}

Ukuran kapal merupakan faktor penting dalam konstruksi khususnya dalam penentuan kapasitas atau daya muat kapal, seperti halnya jumlah $A B K$, muatan mesin, dan muatan alat tangkap yang digunakan. Penentuan ini akan mempermudah nelayan dalam pengoperasian alat tangkap jaring insang, sehingga keseimbangan kapal tetap terjaga.

Kapal penangkap ikan yang digunakan dalam pengoprasian penangkapan yaitu kapal yang berukuran panjang $10 \mathrm{~m}$ dengan lebar 1,5 $\mathrm{m}$ tinggi $1 \mathrm{~m}$. Berdasarkan perhitungan (Lampiran 2) didapatkan kapasitas kapal jaring insang permukaan yang digunakan selama penelitian adalah 2,96 GT. Hal ini sesuai yang dikemukakan oleh Ayodhyoa (1972), bahwa standar ability dari kapal gill net adalah 3 GT.

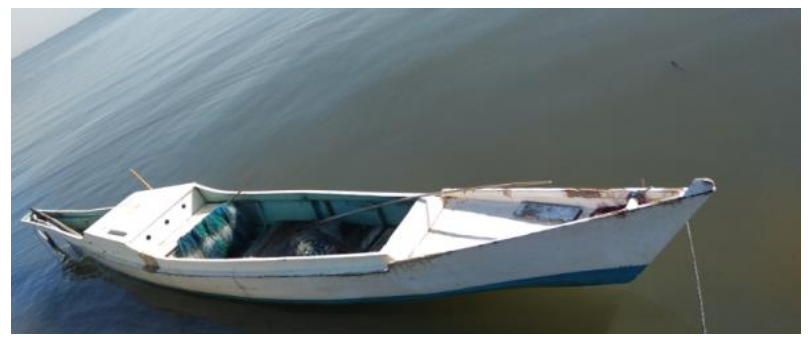

Gambar 5. Kapal yang digunakan untuk mengoperasikan jaring insang permukaan di perairan Kabupaten Maros

\section{Mesin Pengerak (Main Engine)}

Keberadaan mesin penggerak utama kapal diperlukan untuk menggerakkan kapal menuju fishing ground. Berdasarkan hasil penelitian diperoleh spesifikasi mesin penggerak utama yakni menggunakan mesin penggerak utama berkekuatan 22 PK sebanyak 1 unit.

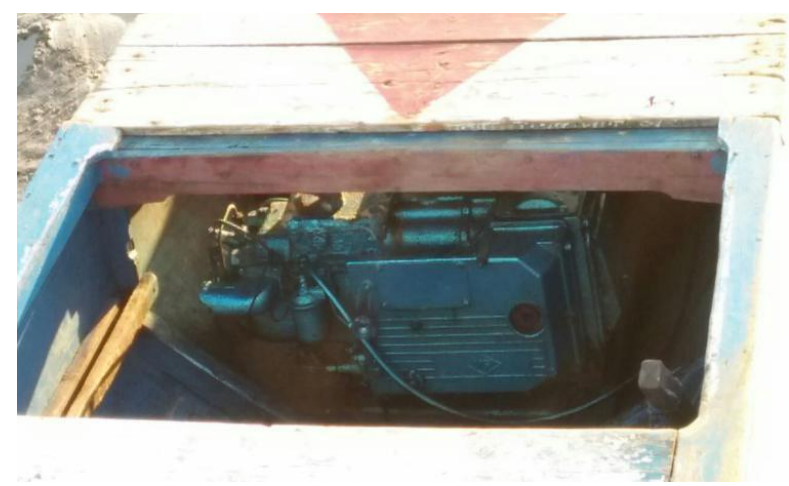

Gambar 6. Mesin penggerak yang digunakan kapal nelayan jaring insang permukaan di perairan Kabupaten Maros

\section{Hubungan Ukuran Kapal, Alat Tangkap dan Mesin pengerak}

Dalam mempertimbangkan efisiensi kegiatan pengoperasian alat tangkap gill net diperlukan beberapa pertimbangan yang didasarkan pada ukuran kapal, alat tangkap dan tenaga penggerak utama.

Berdasarkan hasil pengamatan lapangan diperoleh bahwa ukuran kapal mempengaruhi kuantitas alat tangkap yang dapat dimuat dan dioperasikan, selain itu dalam menjaga stabilitas kapal saat operasi diperlukan pula perhitungan antara besar tenaga penggerak yang dibutuhkan dalam pengoperasian alat tangkap. Nelayan gill net di Kabupaten Maros biasanya memuat jaring sebanyak 9 piece dengan asumsi tangkapan maksimal $50 \mathrm{~kg}$. 
Adapun luas ruang yang digunakan sebagai tempat penyimpanan jaring 1,5 meter persegi.

\section{Tali-temali}

Jaring insang pada umumnya digunakan beberapa tali yaitu tali ris atas, tali pelampung, tali ris bawah, dan tali pemberat. Namun alat tangkap yang digunakan nelayan pada lokasi penelitian hanya menggunakan tali pelampung dan tali pemberat yang difungsikan sebagai tali ris. Tali ris atas yang digunakan sebagai tempat mengikat pelampung dan tali ris bawah sebagai tempat untuk pemberat. Najamuddin dkk (2010) menyatakan nelayan cenderung menggunakan satu tali saja pada bagian atas dan bawah jaring karena pertimbangan efisiensi bahan.

\section{a. Tali pelampung}

Tali pelampung yang digunakan berbahan polyethylene no 3 dengan panjang $30 \mathrm{~m}$. Tali pelampung dipasang dengan cara menyisipkan pada mata jaring tanpa diikat, panjang tali dari mulai ujung badan jaring dilebihkan $35 \mathrm{~cm}$ yang berfungsi untuk mengikatkan pada kayu penanda dan sebagai penghubung antara jaring yang satu dengan yang lainnya pada saat dioperasikan. Pemasangan tali ris pada badan jaring yang berbeda-beda didasarkan pada pertimbangan untuk memudakan operasi penangkapan, penentuan target ikan sasaran dan pertimbangan selektivitas ikan sasaran. Hal ini sesuai dengan pernyataan Martasuganda (2005), bahan yang dipakai untuk tali pelampung dapat sama dengan bahan yang dipakai pada tali pemberat, dan panjang tali dari mulai ujung badan jaring biasanya dilebihkan antara $30-50 \mathrm{~cm}$. Selanjutnya Najamuddin (2009) menyatakan kelebihan tali pelampung dan pemberat dimaksudkan sebagai tempat penyambungan antara satu jaring dengan jaring lainnya pada saat dioperasikan.

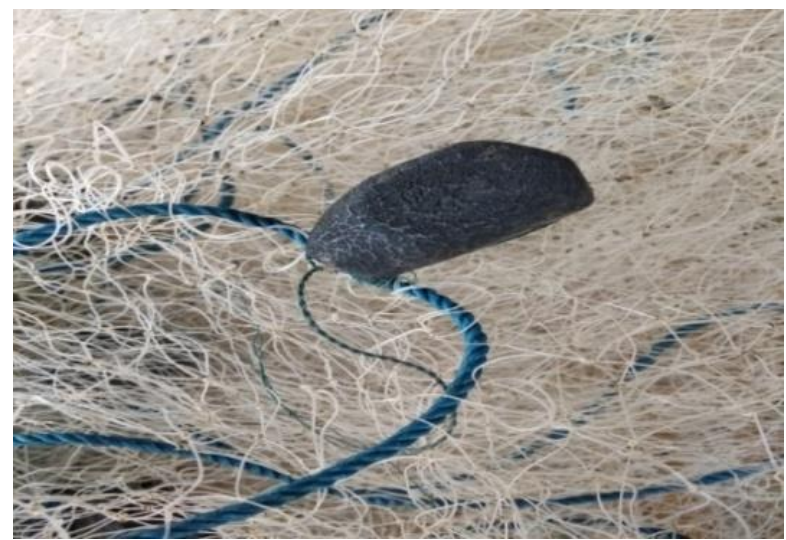

Gambar 7. Tali pelampung yang digunakan pada jaring insang permukaan di perairan Maros 


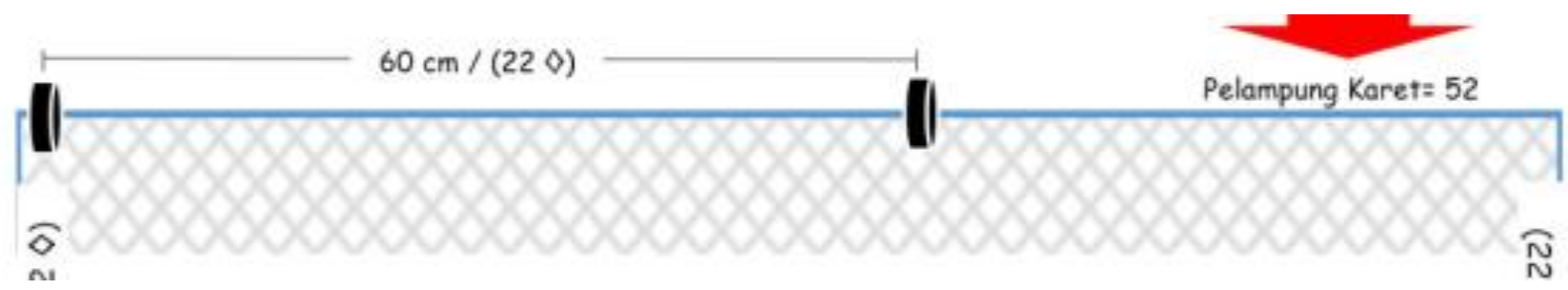

Gambar 8. Jarak antar pelampung

b. Tali pemberat

Tali pemberat terbuat dari bahan yang sama dengan tali pelampung tetapi dengan diameter yang lebih besar. Tali pemberat yang digunakan berbahan polyethylene no.4 dengan panjang yaitu $32,20 \mathrm{~m}$. Tali pemberat dipasang

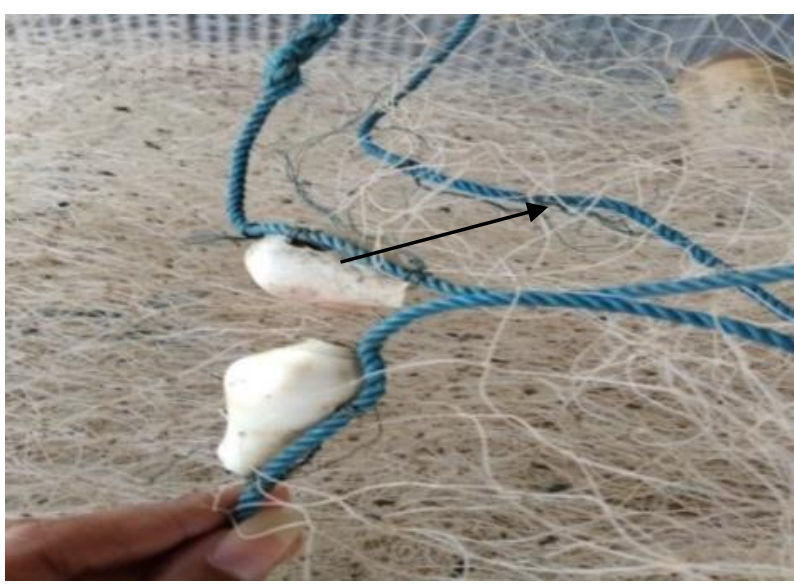

Gambar 9. Tali ris bawah dan pemberat yang digunakan pada jaring insang permukaan di perairan Maros

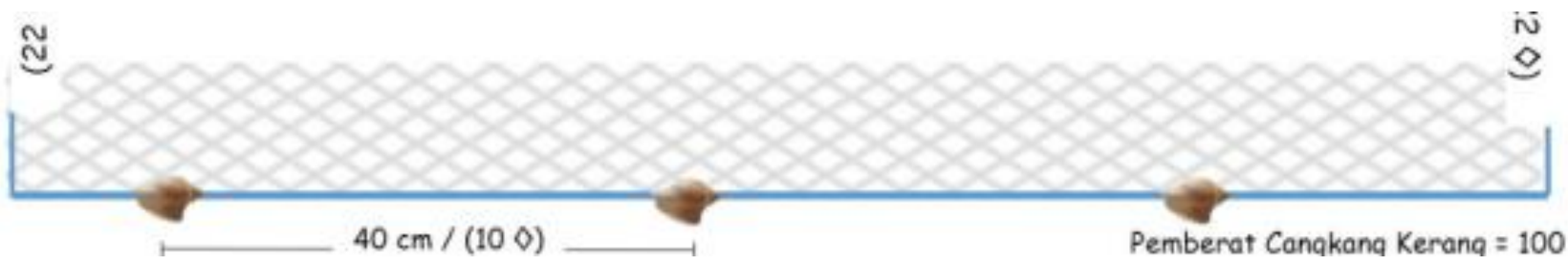

Gambar 10. Jarak antar pemberat

\section{Pelampung}

Pelampung pada jaring insang permukaan ini berfungsi untuk memberikan daya apung pada jaring. Jenis bahan dengan cara menyisipkan pada mata jaring tanpa diikat. Hal ini sesuai dengan pernyataan Martasuganda (2005), bahan yang dipakai untuk tali pelampung dapat sama dengan bahan yang dipakai pada tali pemberat. 
Menurut Martasuganda (2005), jumlah berat jenis dan volume pelampung yang dipakai dalam satu piece akan menentukan besar kecilnya daya apung (bouyancy). Besar kecilnya daya apung yang terpasang pada satu piece akan sangat berpengaruh terhadap baik buruknya hasil tangkapan.

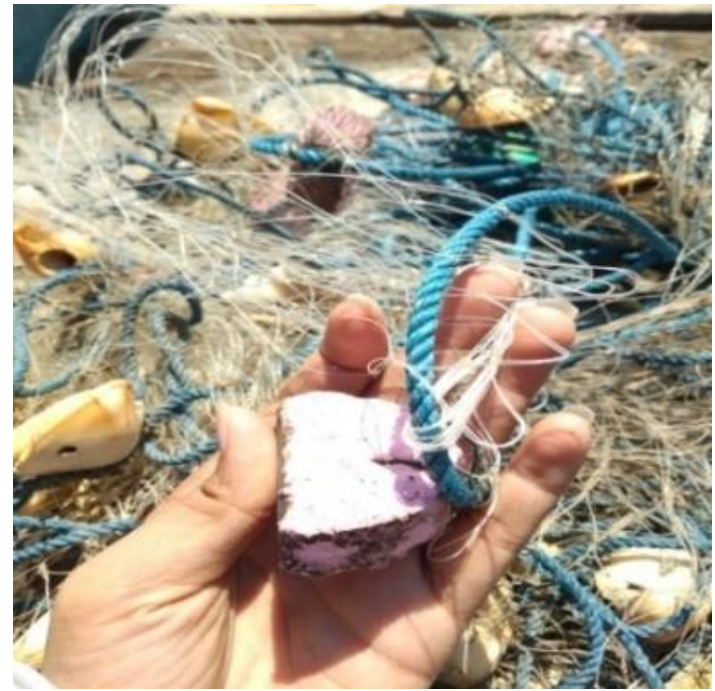

Gambar 11. Pelampung yang digunakan pada jaring insang permukaan di perairan Kabupaten Maros

\section{Pemberat}

Pemberat yang digunakan pada jaring insang permukaan yaitu kulit kerang, pemberat ini berfungsi untuk memberikan gaya tenggelam pada jaring dan mengimbangi daya apung yang diberikan oleh pemberat. Pemberat dipasang pada tali ris bawah, jumlah pemberat yang digunakan yaitu sebanyak 100 buah, dengan jarak antar pemberat $40 \mathrm{~cm}$. Menurut Martasuganda (2005), untuk nelayan jaring insang bahan, ukuran, bentuk dan daya tenggelam dari pemberat biasanya berbeda antara satu nelayan dengan nelayan lainnya meskipun target tangkapannya sama.

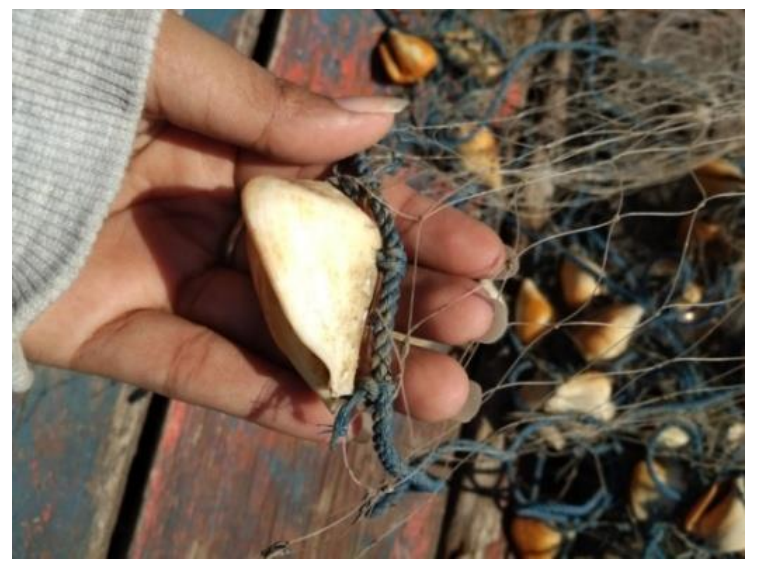

Gambar 12. Pemberat yang digunakan pada jaring insang permukaan di perairan Kabupaten Maros

\section{Kayu Penanda}

Kayu penanda yang digunakan pada jaring insang permukaan berfungsi untuk mengikat kedua ujung tali ris atas agar jaring yang terpasang dapat terentang dengan baik, selain itu sebagai penanda pada kapal-kapal lain untuk memberi informasi bahwa terdapat alat tangkap yang sedang dioperasikan didaerah tersebut.

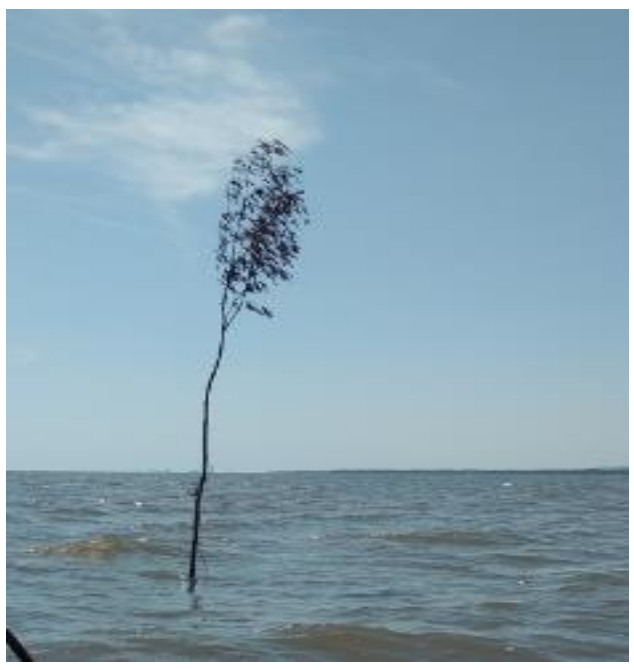

Gambar 13. Kayu penanda 


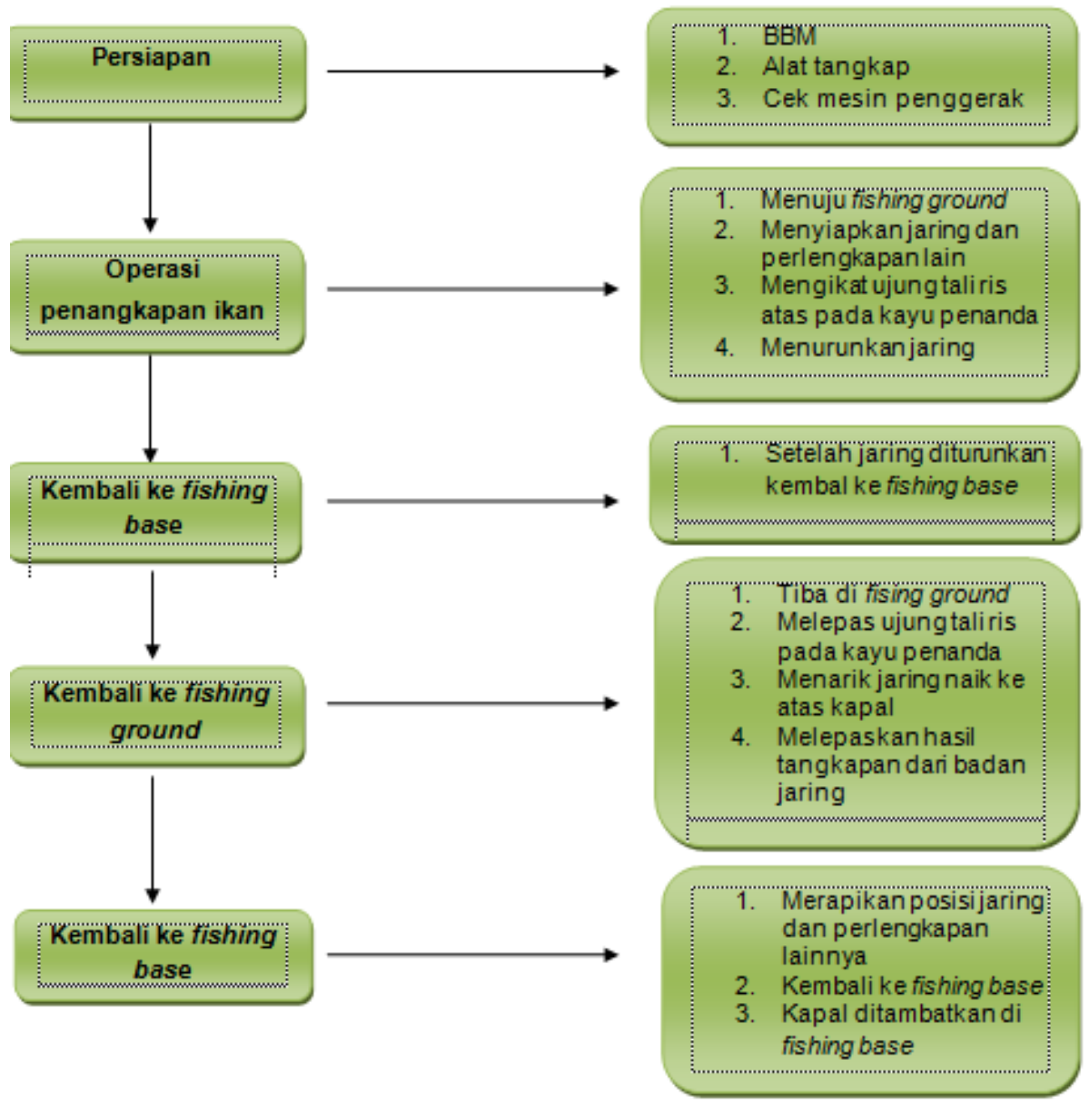

Gambar 14. Alur pengoprasian penangkapan ikan jaring insang permukaan di perairan Kabupaten Maros

\section{Persiapan}

Proses persiapan pemberangkatan dari rumah nelayan menuju fishing base ditempuh selama \pm 10 menit dengan berjalan kaki. Proses penangkapan dilakukan pada pagi hari yaitu pukul 05.30 wita, persediaan tersebut meliputi persiapan bahan bakar solar, dan waktu yang di tempuh dari fishing base ke fishing ground selama $\pm 3-7$ menit.

\section{Proses penangkapan}

a. Perjalanan ke fishing ground

Setelah tiba di fishing base nelayan selanjutnya menuju ke fishing ground. Setelah tiba di fishing ground nelayan mulai 
menentukan posisi atau letak penurunan jaring yang akan diturunkan dengan cara melihat pergerakan bui bui pada air laut dan melihat arah mata angin. Kedalaman daerah penangkapan (fishing ground) berada pada kedalaman 2 - 4 meter.

\section{b. Setting (penurunan jaring)}

Proses setting dilakukan dengan pemasangan jaring dengan cara mengikat kedua $u$ jung tali pada kayu penanda selanjutnya menurunkan jaring insang permukaan di pagi hari selama $\pm 8-10$ menit badan jaring yang di turunkan secara perlahan agar jaring yang di turunkan bisa terbentang dengan baik dan menjaga agar jaring yang diturunkan tidak kusut. Pemasangan jaring dilakukan dengan cara vertikal didalam perairan.

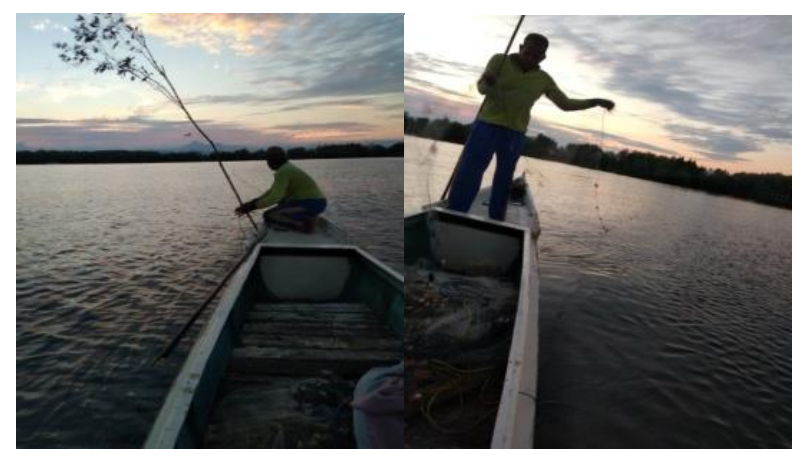

(a)

(b)

Gambar 15. (a) Mengikat ujung tali pada kayu penanda (b) penurunan jaring

\section{c. Hauling (penarikan jaring)}

Proses penarikan jaring mulai dilakukan pada pukul 13.00 wita. Sebelum melakukan penarikan jaring terlebih dahulu nelayan melepaskan tali ris atas pada kayu penanda selanjutnya menarik jaring dengan perlahan lalu dinaikkan keatas kapal. Waktu yang dibutuhkan selama proses hauling yaitu \pm 10 20 menit.

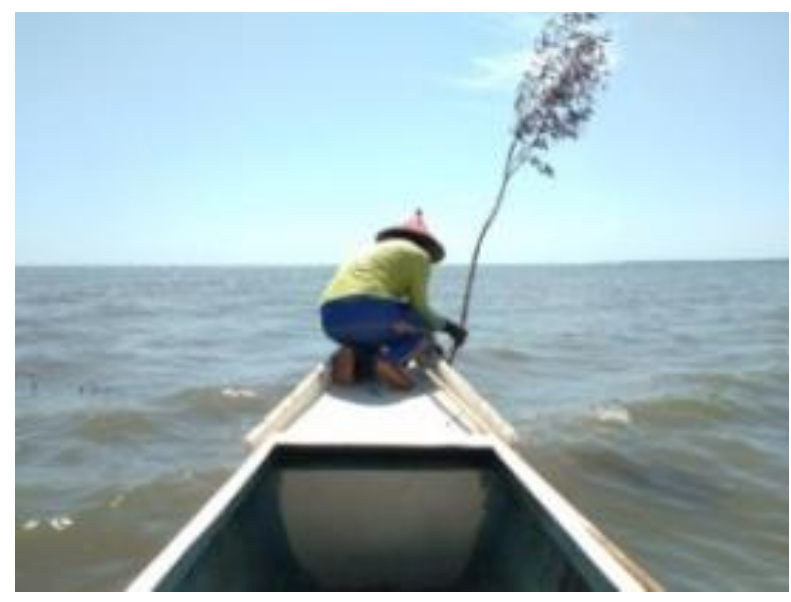

(a)

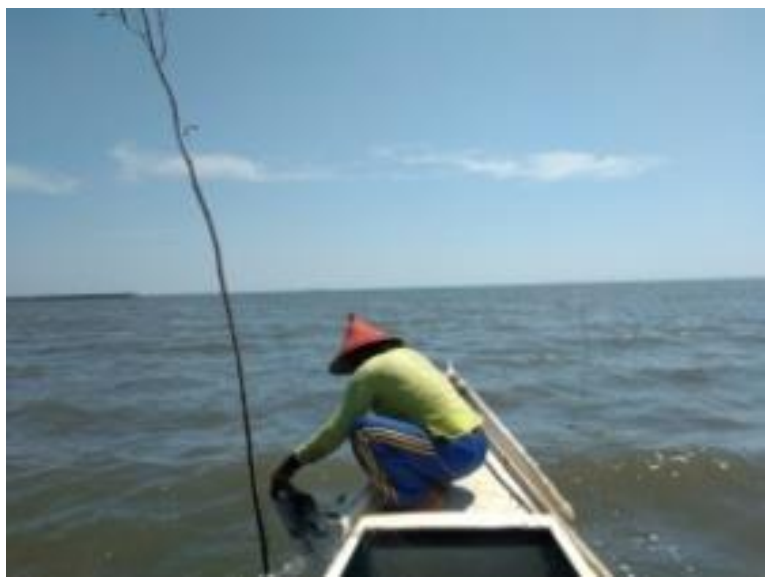

(b)

Gambar16. (a) Melepas tali pada kayu penanda (b) penarikan jaring

Hasil tangkapan yang tertangkap pada jaring insang permukaan umumnya terjerat dengan insang, hasil tangkapan yang tertangkap kemudian di lepas dan di masukkan 
kedalam ember tampa memberikan penanganan karena men urut nelayan selain dari jarak fishing ground ke fising base dekat, ikan yang tertangkap langsung di jual ke pembeli yang berada didekat rumah nelayan.

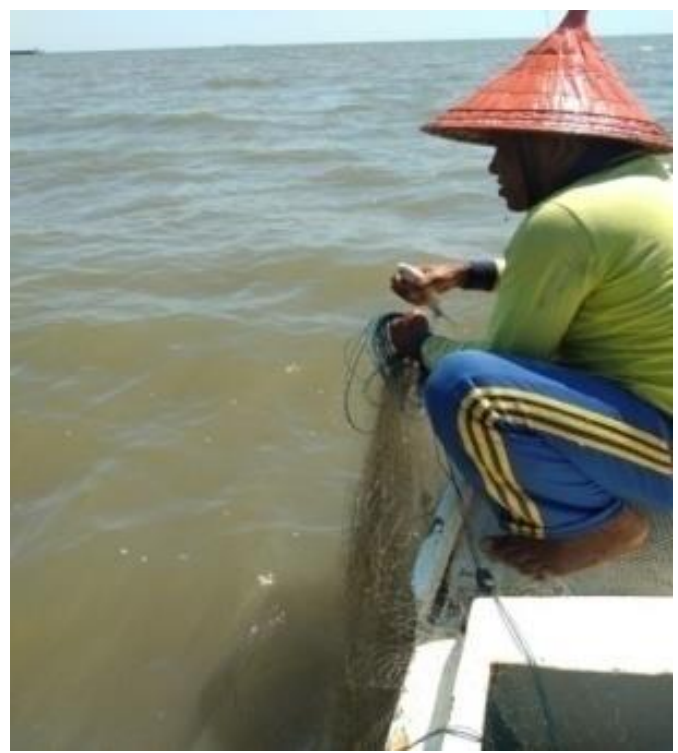

Gambar 17. Melepas hasil tangkapan pada badan jaring

A. Analisis Hasil Konstruksi Alat Tangkap Perhitungan dari analisis data dapat dilihat pada (Lampiran 3) dengan hasil sebagai berikut :

\section{Shortening}

Prinsip tertangkapnya ikan pada jaring insang permukaan adalah adanya ikan-ikan yang menabrak dinding jaring yang dipasang di permukaan perairan surface water. Salah satu yang mempengaruhi yaitu nilai shortening prinsip tertangkapnya apakah target tangkapan terjerat, terbelit, atau terpuntal.
Pada jaring insang permukaan yang beroperasi di perairan Kabupaten Maros mempunyai shortening pada bagian atas lebih besar dari shortening pada bagian bawah. Nilai shortening atas 58,7 \% dan shortening bawah $55,67 \%$. Hal ini sesuai menurut Sudirman dan Mallawa (2004) bahwa pada gillnet, shortening ini lebih berpengaruh pada ikan hasil tangkapan, untuk gillnet yang ikannya tertangkap secara gilled, nilai shortening bergerak sekitar 30 - 40 \% dan untuk yang tertangkapnya ikan secara entangled maka nilai shortening bergerak sekitar 35 - $60 \%$. Nilai shortening pada bagian atas lebih besar dibandingkan pada bagian bawah agar ukuran alat tangkap pada bagian bawah menjadi lebih panjang dibanding bagian atas, dengan tujuan agar posisi alat tangkap pada saat dioperasikan dapat terentang dengan baik di dalam perairan. Menurut Martasuganda (2005), nilai pengerutan pada tali ris atas sebaiknya nilainya sedikit lebih besar dari pada nilai pengerutan pada tali ris bawah, dengan tujuan agar posisi jaring sewaktu dioperasikan dapat terentang dengan baik di dalam perairan. Namun demikian berdasarkan catalog nilai shortening antara bagian atas dan bawah jaring sama (BBPPI, 2009). Kondisi ini menunjukkan terdapat perbedaan antara teori dan di 
lapangan dimana menurut nelayan jaring akan lebih lincah menjerat ikan apabila shortening jaring pada bagian atas lebih besar dari pada bagian bawah jaring. Pada kondisi ini, jaring bagian bawah agak berkerut sedikit, jaring tidak terlalu tegang di dalam air, akibatnya ikan akan lebih mudah terjerat atau terbelit pada jaring.

\section{Tinggi jaring dan luas jaring}

Tinggi jaring yang digunakan pada jaring insang permukaan di perairan Kabupaten Maros adalah 1,27 $\mathrm{m}$, nilai tinggi jaring dipengaruhi oleh nilai shortening atas pada jaring. Semakin besar nilai pengerutan (shortening) maka semakin besar pula tinggi jaring, hal ini sesuai dengan pernyataan Nomura dan Yamazaki (1978), nilai shortening sangat berpengaruh terhadap tinggi atau kedalaman jaring (d), semakin besarnya nilai (d) juga akan besar. Selanjutnya Najamuddin (2009) bahwa ada dua akibat yang ditimbulkan oleh adanya shortening yaitu panjang jaring akan semakin memendek dan kedalaman jaring akan semakin bertambah serta menentukan proses tertangkapnya ikan pada jaring. Berdasarkan hasil perhitungan nilai luas jaring pada jaring insang permukaan yang dioperasikan di Kabupaten Maros yaitu 38,95 $\mathrm{m}^{2}$.

\section{Daya Apung dan Daya Tenggelam}

Daya apung dan daya tenggelam timbul karena adanya perbedaan antara berat jenis bahan pembentuk alat tangkap dengan berat jenis air laut. Perbedaan daya apung dan daya tenggelam menentukan kedudukan dari alat tangkap dalam perairan. Tujuannya adalah daya apung dan daya tenggelam merata pada seluruh badan jaring insang. atau dengan kata lain, bukaan mata jaring akan sama disemua tempat di seluruh permukaan webbing. Total daya apung. Perbandingan dari nilai daya apung dan daya tenggelam dari alat tangkap jaring insang permukaan menunjukkan daya apung lebih besar dibanding dengan daya tenggelam. Hal ini menunjukkan bahwa alat tangkap tersebut sesuai untuk dioperasikan di permukaan perairan, hal ini sesuai menurut Martasuganda (2005) besar kecilnya daya apung terpasang pada satu piece akan sangat berpengaruh terhadap baik buruknya hasil tangkapan. Jumlah pemberat jenis dan volume pelampung yang dipakai akan sangat menentukan besar kecilnya daya apung.

Daya apung tali ris atas yaitu sebesar 7,716 g sedangkan tali ris bawah 11,76 g, panjang tali ris yang digunakan pada jaring 
insang permukaan di perairan Kabupaten Maros yaitu tali ris bawah lebih panjang dari tali ris atas.

Hasil Tangkapan Jaring Insang Permukaan

$$
\text { Hasil tangkapan jaring insang }
$$
permukaan menangkap ikan kwee (Caranx sp.) dengan panjang 13,5-19,8 cm, ikan senangin (Eleutheronema tetradacttylum) dengan panjang 16,2-22,7 cm, ikan bandeng (Chanos chanos) dengan panjang 18,2-23,5 cm dan ikan parang-parang (Chirocentrus dorab) 19,5-27,6 $\mathrm{cm}$.
Analisis Komposisi Hasil Tangkapan

Berdasarkan hasil penelitian diperoleh 4 jenis hasil tangkapan yang dominan anatara lain ikan kwee (Caranx sp.), ikan senangin (Eleutheronema tetradacttylum ), ikan bandeng (Chanos chanos) dan ikan parang-parang (Chirocentrus dorab).

\section{a. Total Hasil Tangkapan Per Trp}

Berdasarkan hasil penelitian diperoleh data mengenai total hasil tangkapan per trip selama 30 trip dapat dilihat pada Gambar 19.

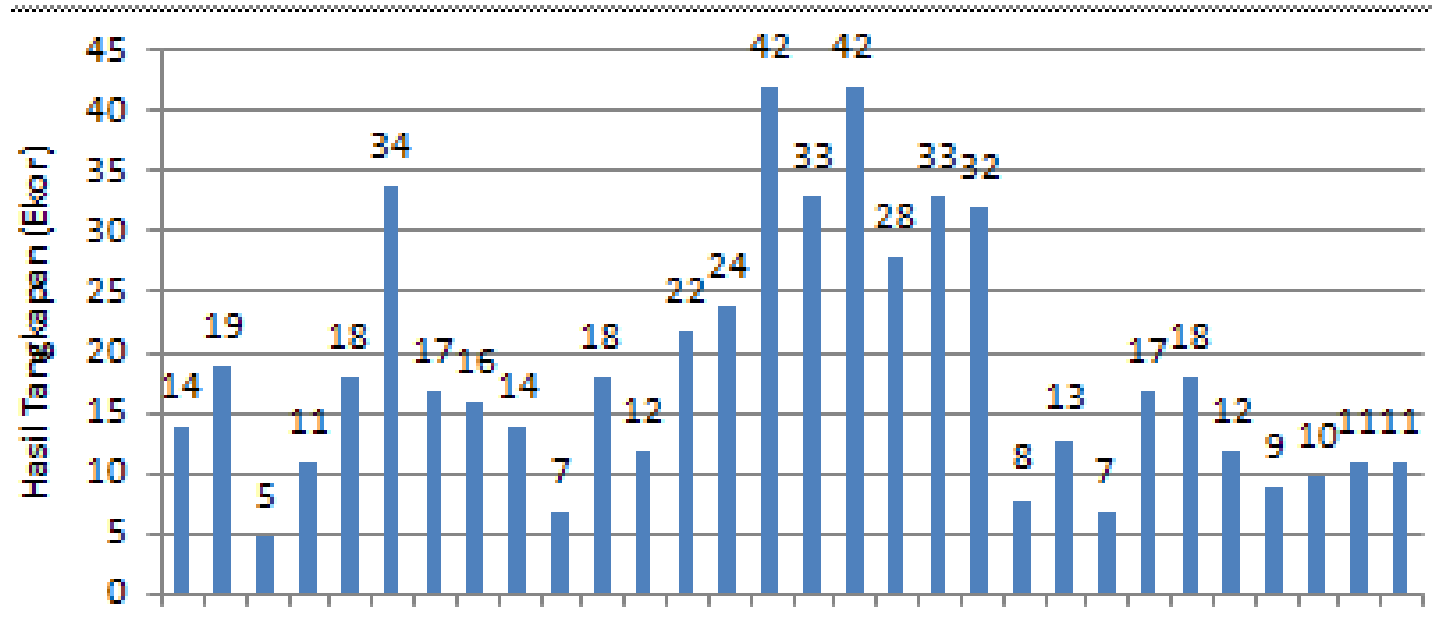

123456789101112131415161718192021222324252627282930

Trip

Gambar 18. Diagram total hasil tangkapan per trip (ekor) pada pengoprasian jaring insang permukaan di perairan Kabupaten Maros

Gambar 19 menunjukkan bahwa hasil tangkapan terbanyak pada trip ke-17 dengan hasil tangkapan sebanyak 42 ekor, sedangkan pada hasil tangkapan sedikit berada pada trip ke - 3 sebanyak 5 ekor. Total hasil tangkapan jaring insang permukaan selama penelitian 557 ekor dengan rata-rata 18 ekor (Lampiran 4). Hal ini dipengaruhi oleh pergeseran titik koordinat atau lokasi penangkapan sehingga hasil tangkapan bervariasi. Selain itu, hasil 
tangkapan yang jumlahnya bervariasi dipengaruhi oleh faktor makanan. Seperti yang dikemukakan oleh Susilo dkk, 2013 bahwa kelimpahan ikan juga sangat tergantung pada ketersediaan makanan. Sumberdaya ikan menduduki tingkat trofik atas dan tengah dalam rantai makanan di laut. Kelimpahan dan keberadaannya bergantung pada jumlah biomassa pada tingkat trofik yang lebih rendah yaitu fitoplankton dan zooplankton.

Pada Gambar 19 dapat dilihat bahwa hasil tangkapan pada 20 trip pertama, produksi hasil tangkapan bervariasi. Sedangkan pada trip 10 terakhir produksi hasil tangkapan relatif rendah. Hal ini diduga karena pada 10 trip terakhir, kekeruhan perairan meningkat. Menurut Hamuna (2018) akan dijumpai berbagai jenis sampah dan bahan pencemar di laut, hal tersebut tentu dapat mengakibatkan degardasi lingkungan di wilayah pesisir dan ekosistem di sekitarnya. Sehingga masuknya zat-zat organik dan anorganik ke badan air secara berlebihan dan berdampak pada tingkat kekeruhan air laut yang signifikan.

\section{b. Komposisi Hasil Tangkapan}

Jenis dan total (ekor) hasil tangkapan selama penelitian dapat dilihat pada Tabel 2 .

Tabel 2. Jenis dan total hasil tangkapan jaring insang permukaan

\begin{tabular}{llr}
\hline NO & \multicolumn{1}{c}{ Jenis Ikan } & Total (ekor) \\
\hline $\mathbf{1}$ & Kwee & 174 \\
\hline $\mathbf{2}$ & Senangin & 150 \\
\hline $\mathbf{3}$ & Bandeng & 125 \\
\hline $\mathbf{4}$ & Parang-parang & 108 \\
\hline & Total & $\mathbf{5 5 7}$ \\
\hline
\end{tabular}

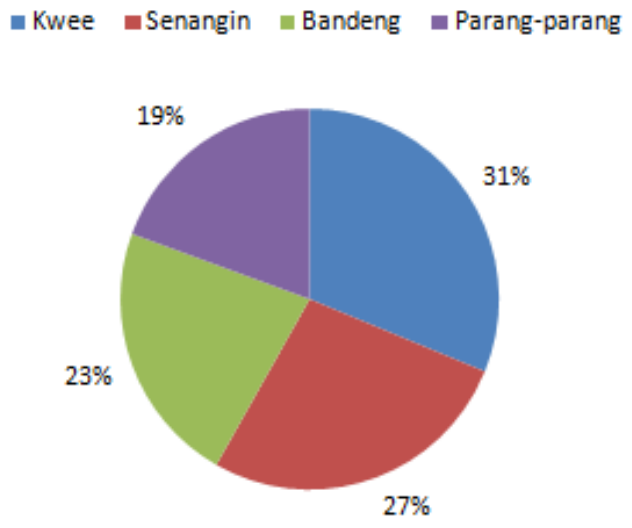

Gambar 19. Diagram persentase komposisi hasil tangkapan (ekor) pada pengoprasian jaring insang permukaan di perairan Kabupaten Maros

Berdasarkan Gambar 20 dapat diketahui bahwa persentase komposisi hasil tangkapan jaring insang permukaan selama penelitian yaitu ikan kwee (Caranxsp.) merupakan hasil 
tangkapan yang mendominanasi dengan total hasil tangkapan sebanyak 31\% (174 ekor) dan adapun hasil tangkapan lain yang tertangkap selama penelitian adalah ikan senangin (Eleutheronema tetradactty/um ) 27\% (150 ekor), ikan bandeng (Chanos chanos) 23\% (125 ekor), dan ikan parang-parang (Chirocentrus dorab) sebanyak 19\% (108 ekor).

Hasil tangkapan jaring insang permukaan yang diperoleh selama penelitian berkisar antara 5 - 42 ekor $(0,6 \mathrm{~kg}-4,4 \mathrm{~kg})$. Berdasarkan hasil wawancara, hasil tangkapan yang di peroleh berkisar 15 - 65 ekor ( 2 kg $20 \mathrm{~kg}$ ). Rendahnya hasil tangkapan selama penelitian disebabkan oleh pelaksanaan penelitian yang dilakukan bukan pada musim puncak penangkapan ikan target tangkapan, sehingga mempengaruhi rendahnya hasil tangkapan di setiap trip penangkapan. Hal ini didukung oleh pernyataan Aspirandi, 2015 bahwa nelayan yang melakukan penangkapan diluar musim puncak target tangkapan akan memperoleh hasil tangkapan yang kurang maksimal atau tidak seperti biasanya. Kondisi ini dipengaruhi oleh tingkat toleransi tubuh ikan terhadap arus ataupun kondisi oseanografi lainnya yang tidak sesuai dengan tubuh ikan. Selain itu, sebagian jenis ikan pada musim tersebut berpindah lokasi atau bermigrasi sehingga hasil tangkapan yang diperoleh saat penurunan gill net hanya sedikit.

\section{c. Ukuran Hasil Tangkapan}

a) Ukuran Panjang Ikan Kwee (Caranx sp.) Ukuran panjang ikan kwee yang tertangkap pada jaring insang permukaan selama 30 trip penangkapan di perairan Kabupaten Maros dapat dilihat pada Gambar 21.

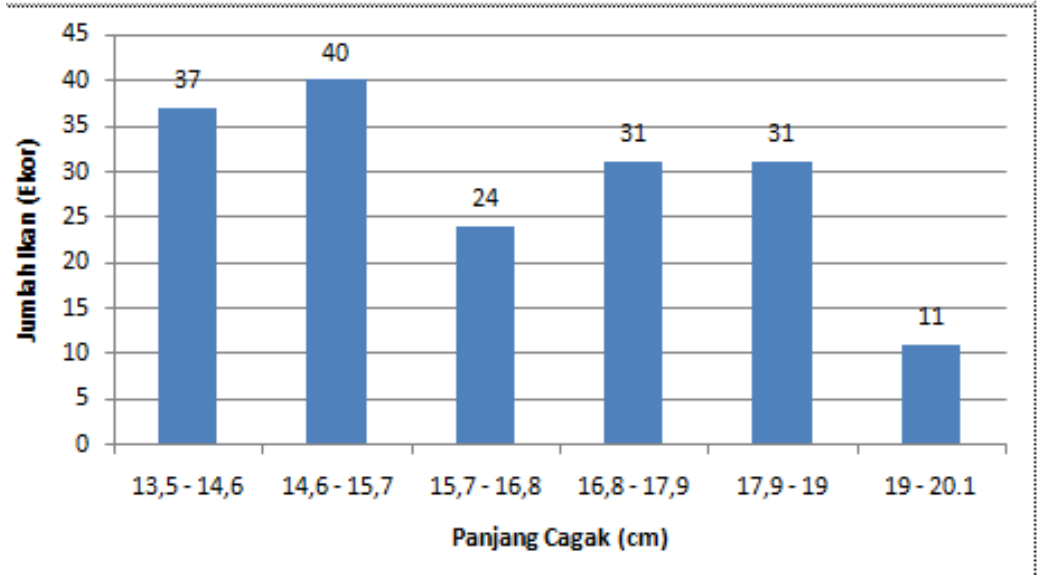

Gambar 20. Diagram panjang cagak ikan kwee (Caranx sp.) yang tertangkap pada jaring insang permukaan di perairan Kabupaten Maros 
Pada Gambar 21 panjang cagak ikan kwee yang tertangkap berada pada kisaran 13,5 - 20,1 cm. Frekuensi terbesar terdapat pada selang kelas 14,6 - 15,7 dengan jumlah ikan 40 ekor, sedangkan frekuensi terkecil terdapat pada selang kelas 19 - 20,1 dengan jumlah ikan 11 ekor. (Bubun dan Mahmud, 2015) menyatakan ikan Caranx sp. sudah layak tangkap pada ukuran $70-77 \mathrm{~cm}$ dengan nilai length at first maturity (LM) $50 \mathrm{~cm}$. Jika dilihat dari panjang cagak ikan yang tertangkap, ikan kwee masih tergolong kecil atau belum layak tangkap. Berdasarkan data hasil tangkapan di dapatkan persentase ikan kwee 100 \% belum layak tangkap.

\section{b) Ukuran Panjang Ikan Senangin (Eleutheronema tetradacttylum )}

Ukuran panjang ikan senangin yang tertangkap pada jaring insang permukaan selama 30 trip penangkapan di perairan Kabupaten Maros dapat dilihat pada Gambar 22.

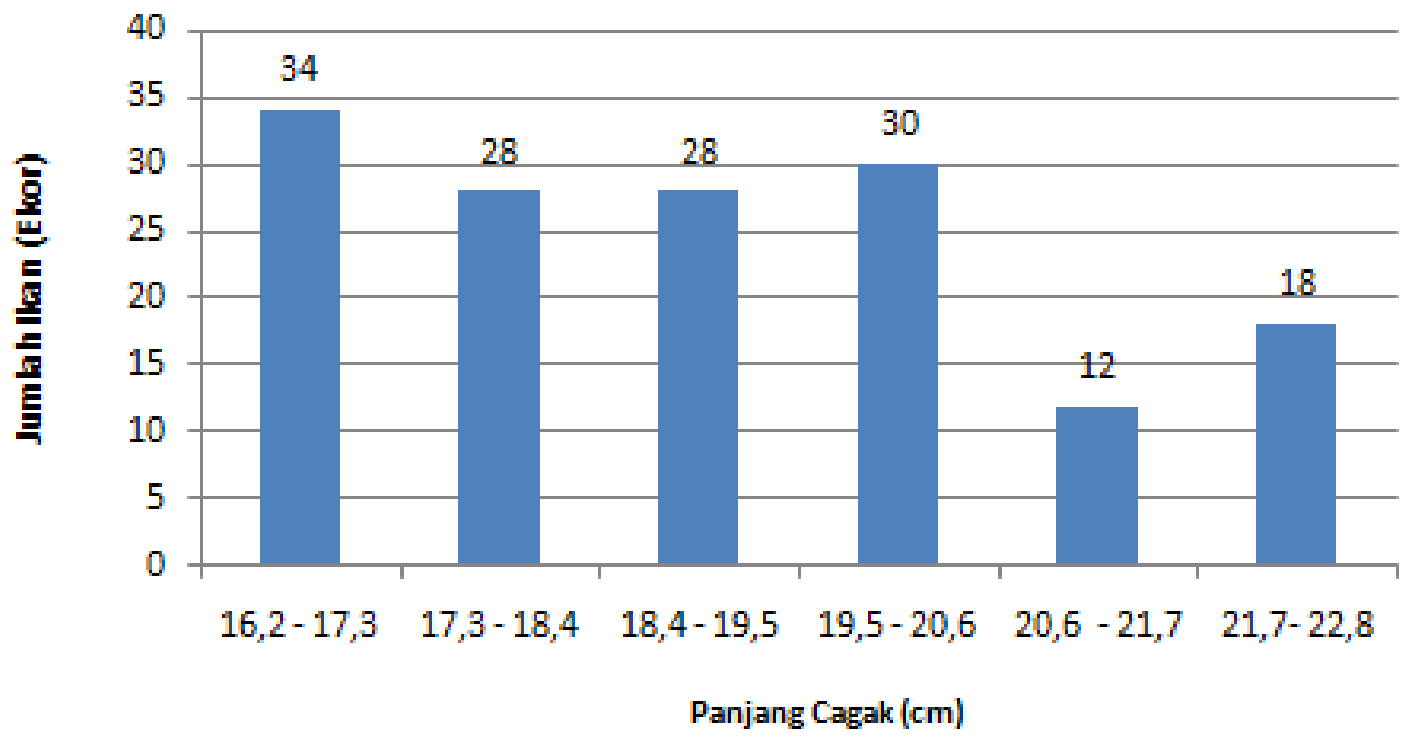

Gambar 21. Diagram panjang cagak ikan senangin (Eleutheronema tetradactty/um) yang tertangkap pada jaring insang permukaan di perairan Kabupaten Maros

Pada Gambar 22 panjang cagak ikan senangin yang tertangkap berada pada kisaran $16,2-22,8 \mathrm{~cm}$. Frekuensi terbesar terdapat pada selang kelas 16,2 - 17,3 dengan jumlah ikan 34 ekor, sedangkan frekuensi terkecil terdapat pada selang kelas 20,6 - 21,7 cm dengan jumlah ikan 12 ekor.

Ukuran ikan senangin yang layak tangkap, berdasarkan nilai Lm (Length Maturity) ikan senangin menurut Kholis dkk 
(2017), yaitu 350 mm (35 cm) untuk jantan dan $450 \mathrm{~mm}(45 \mathrm{~cm})$ untuk ikan betina. Dengan demikian, hasil tangkapan ikan senangin yang diperoleh tidak termasuk dalam kategori ikan layak tangkap berdasarkan peraturan yang berlaku. Berdasarkan data hasil tangkapan di dapatkan persentase ikan senangin $100 \%$ belum layak tangkap.

\section{c) Ukuran Panjang Ikan Bandeng (Chanos chanos)}

Ukuran panjang ikan bandeng yang tertangkap pada jaring insang permukaan selama 30 trip penangkapan di perairan Kabupaten Maros dapat dilihat pada Gambar 23.

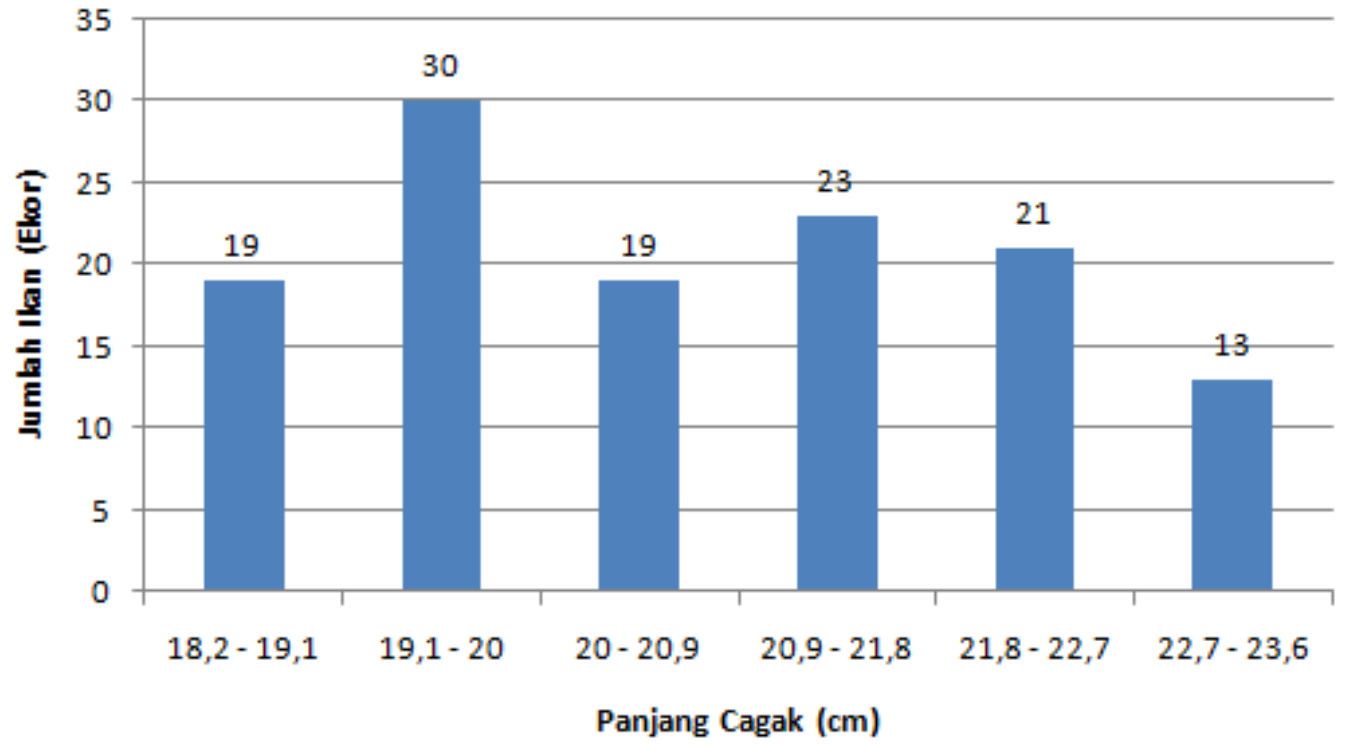

Gambar 22. Diagram panjang cagak ikan bandeng (Chanos chanos) yang tertangkap pada jaring insang permukaan di perairanKabupaten Maros

Pada Gambar 23 panjang cagak ikan bandeng yang tertangkap berada pada kisaran 18,2 - 23,6 cm. Frekuensi terbesar terdapat pada selang kelas 19,1 - $20 \mathrm{~cm}$ dengan jumlah ikan 30 ekor, sedangkan frekuensi terkecil terdapat pada selang kelas 22,7 - 23,6 dengan jumlah ikan 13 ekor. Ikan bandeng merupakan ikan air payau yang memiliki persebaran yang luas, selama musim kawin ikan ini berada di pesisir pantai dan pada musim hujan ikan ini akan bermigrasi sesuai dengan toleransi tubuhnya terhadap tingkat kekeruhan air laut (Sembiring dkk, 2018). Hal inilah yang mempengaruhi tinggi rendahnya perolehan hasil tangkapan berdasarkan ukuran ikan bandeng. 
d) Ukuran Panjang Ikan Parang-parang (Chirocentrus dorab)

Ukuran panjang ikan parang-parang yang tertangkap pada jaring insang permukaan selama 30 trip penangkapan di perairan Kabupaten Maros dapat dilihat pada Gambar 24.

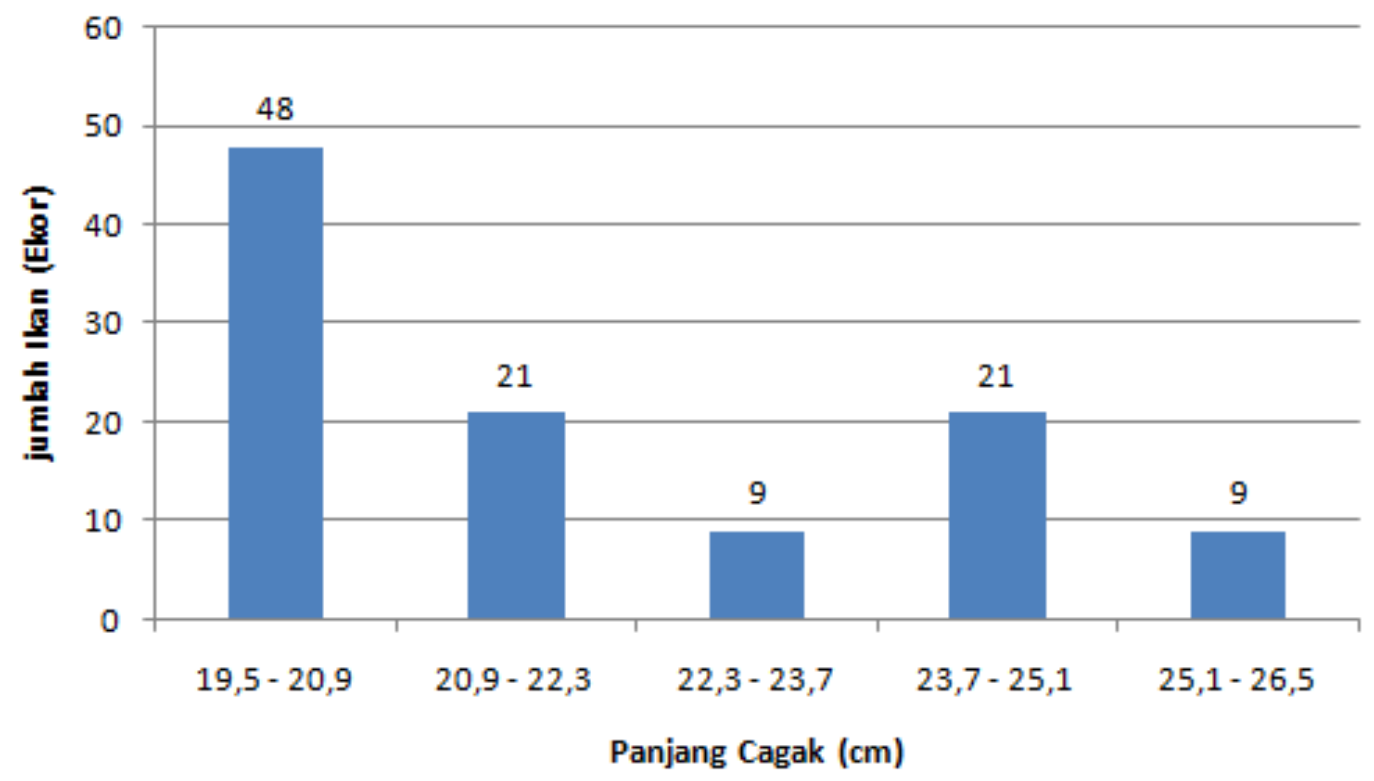

Gambar 23. Diagram panjang cagak ikan parang-parang(Chirocentrusdorab)yang tertangkap pada jaring insang permukaan di perairan Kabupaten Maros

Pada Gambar 24 panjang cagak ikan parang-parang yang tertangkap berada pada kisaran 19,5 - 26,5 cm. Frekuensi terbesar terdapat pada selang kelas $19,5-20,9 \mathrm{~cm}$ dengan jumlah ikan 48 ekor, sedangkan frekuensi terkecil terdapat pada selang kelas 22,3 - 23,7 dan interval 25,1 - 26,5 dengan jumlah ikan 9 ekor. Penangkapan ikan parangparang efektif dilakukan di luar pada musim bertelur yaitu September - Desember (Fitriadi, 2013). Namun pada penelitian ini, penangkapan dilakukan bukan pada musim puncak ikan parang-parang sehingga hasil tangkapan yang diperoleh tergolong variatif berdasarkan ukuran pangjang cagak. Berdasarkan hasil penelitian ini, jumlah ikan parang-parang yang diperoleh tidak termasuk dalam kategori layak tangkap, sesuai dengan (Martalena dkk, 2012) bahwa ukuran layak tangkap dapat dilihat dari kematangan gonad pada ukuran panjang tubuh diantaranya ikan jantan 32,1 - $59 \mathrm{~cm}$ sedangkan pada ikan betina 56,5 - 69,1 cm. Berdasarkan data hasil tangkapan di dapatkan persentase ikan parang-parang $100 \%$ belum layak tangkap. 


\section{KESIMPULAN}

Jaring insang permukaan yang dioperasikan di perairan Kabupaten Maros memiliki konstruksi yakni terdiri atas pelampung, pemberat, tali pemberat, tali pelampung dan badan jaring. Adapun nilai shortening atas pada jaring 58,7 \% dan shortening bawah 55,67 \%. Jaring insang permukaan yang beroperasi di perairan Kabupaten Maros memiliki mesh size jaring 2,5 inci $(6,35 \mathrm{~cm})$ jenis hasil tangkapan yaitu ikan pelagis kecil yang terdiri atas spesies ikan kwee (Carangoides coeruleopinnatus) dengan panjang 13,5-19,8 cm, ikan senangin (Eleutheronema tetradacttylum ) dengan panjang 16,2-22,7 cm, ikan bandeng (Chanos chanos) dengan panjang 18,2-23,5 cm dan ikan bandeng lelaki (Elops hawaiensis) 19,5-27,6 cm.

\section{DAFTAR PUSTAKA}

Affandy, A. 2010. Studi Rancang Bangun Jaring Insang Hanyut Ikan Terbang di Perairan Kecamatan Galesong Selatan Kabupaten Takalar. (Skripsi). Program Studi Pemanfaatan Sumber Daya Perikanan Jurusan Perikanan Fakultas Ilmu Kelautan dan Perikanan Universitas Hasanuddin. Makassar.

Aspirandi, Y. 2015. Optimalisasi Ooperasi Penangkapan Perikanan Gill Net di PPN Sungai Liat Kabupaten Bangka. (Thesis). Prorgam Pascasarjana Universitas Terbuka. Magister Ilmu
Kelautan Bidang Minat Manajemen Perikanan. Bangka.

Ayodhyoa, A.U. 1981. Metode Penangkapan Ikan. Yayasan Dewi Sri. Bogor. Hal :1418.

Ayodhyoa, A.U. 1972. Fishing Boat. Institut Pertanian Bogor. Bogor.

BBPPI, 2009. Katalog Alat Penangkapan Ikan Indonesia. Balai Besar Pengembangan Penangkapan Ikan, Semarang.

Bubun, R.L. dan A. Mahmud. 2015. Komposisi Hasil Tangkapan Pukat Cincin Hubungannya dengan Teknologi Penangkapan Ikan Ramah Lingkungan. Marine Fisheries. Vol. 6 (2): 177-186.

DKP Maros. 2015. Letak Geografis Kabupaten Maros.

https://maroskab.go.id/geografi diakses pada tanggal 13 November 2017.

Fitriadi, A.F. 2013. M trik dan Meristik Ikan Banueng lelaki (Elops hawaiensis Forsskal, 1775) di Perairan Bengkalis. (Skripsi). Jurusan Biologi Fakultas Matematika dan Ilmu Pengetahuan Alam. Universitas Riau.

Fridman, A.L. 1986. Terjemahan Perhitungan Dalam Merancang Alat Penangkapan Ikan. Balai Pengembangan Ikan. Semarang.

Hamuna, B., H.R.T. Rosye, Suwito, K.M. Hendra, dan Alianto. 2018. Kajian Kualitas Air Laut dan Indeks Pencemaran Berdasarkan Parameter Fisika-Kimia di Perairan Distrik Depapre, Jayapura. Jurnal Ilmu Lingkungan 16(1): 35-43. 
Kholis, M.N., R.I. Wahju, dan Mustaruddin. 2017. Seleksi Unit Teknologi Penangkapan Ikan Kurau Eleutheronema tetradacttylum yang Unggulan dan Berkelanjutan. Jurnal Ilmu dan Teknologi Kelautan Tropis. Vol. 9 (245) : 521-535.

Laila, K. 2017. Analisis Hasil Tangkapan Jaring Insang Permukaan Ditinjau Dari Oseanografi Pada Pagi, Sore Dan Malam Hari Diteluk Tapian Nauli Kota Sibolga Tapanuli Tengah. Universitas asahan.

Mallawa, A. 2012. Dasar-dasar Penangkapan Ikan. Masagena Press. Makassar. 201 hal.

Martalena ,L., Elvyra R., dan Yusfianti. 2012. Aspek Reproduksi Ikan Bandeng lelaki (Elops hawaiensis Forsskal 1775) di Perairan Laut Bengkalis Kabupaten Bengkalis Provinsi Riau. Universitas Binawidya Pekanbaru. Pekanbaru.

Martasuganda, S. 2002. Jaring Insang (Gill net). Serial Teknologi Penangkapan Ikan Bewawasan Linkungan. Bogor. Jurusan Pemanfaatan Sumberdaya Perikanan, Fakultas Perikanan dan Ilmu Kelautan, Institut Pertanian Bogor. 68 hal.

Martasuganda, S. 2005. Jaring Insang (Gill net) Serial Teknologi Penangkapan Ikan Berwawasan Lingkungan. Departemen PSP, FIKP IPB Bogor.

Martasuganda, S. 2008. Jaring Insang (Gill net). Departemen Pemanfaatan Sumberdaya Perikanan dan Pusat Kajian Sumberdaya Pesisir dan
Lautan.Bogor (ID): Institut Pertanian Bogor.

Najamuddin. 2009. Modul of Fishing Gear Design. Faculty of Marine Science and Fishiries, Hasanuddin University, Makassar. Unpublished.

Najamuddin, A. Taufik, dan M. Palo. 2011. Rancang Bangun Jaring Ikan Terbang di Perairan Kabupaten Takalar Sulawesi Selatan. Seminar Nasional Perikanan dan Kelautan. Riau

Najamuddin. 2012. Rancang Bangun Alat Penangkapan Ikan. Arus Timur. Makassar.

Nomura, M. dan Yamazaki T.1978. Fishing Techiques. Japan Internasional Cooperatioo Agency. Tokyo. 206 Hal.

Odum, E.P. 1996. Dasar-dasar Ekologi ( Terjemahan T. Samingan ) Edisi ketiga, cetakan ketiga. Gadja Mada University Press. Yogyakarta. 697 hal.

Prado, J. dan P.Y. Dremiere. 1991. Petunjuk Praktis Bagi Nelayan. Organisasi Pangan dan Pertanian PBB. Semarang.

Puspito, G. 2009. Perubahan Sifat-sifat Mata Jaring Insang Setelah digunakan 5, 10, 15, dan 20 Tahun. Jurnal Penelitian Sains Vol. 12 Nomor 39 (D). Departemen Pemanfaatan Sumberdaya Perikanan, FPIK-IPB, Bogor, Indonesia.

Sadhori, N. 1984. Bahan Alat Penangkapan Ikan. CV Yasaguna. Jakarta.

Moria, S.S.B., Wibawa G.S., Setiadharma T., dan Haryanti. 2018. Pertumbuhan dan Variasi Genetik Ikan Bandeng, Chanos chanos dari Provinsi Aceh, 
Bali, dan Gorontalo Indonesia. Balai Besar Riset Laut dan Penyuluhan Perikanan 12(4): 307-314

Subani, W. dan Barus H.R. 1989. Alat Penangkapan Ikan dan Udang Laut di Indonesia. Jurnal Penelitian Perikanan Laut. No. 50. Jakarta: Balai Penelitian Perikanan Laut Badan Penelitian dan Pengembangan Pertanian, Departemen Pertanian.

Sudirman dan Mallawa A. 2012. Teknik Penangkapan Ikan. Rineka Cipta: Jakarta.

Susilo, E., Islamy F., Saputra A.J., Hidayat J.J., Zaky A.R., dan Suniada K.I. 2013. Pengaruh Dinamika Oseanografi Terhadap Hasil Tangkapan Ikan Pelagis PPN Kejawanan dari Data Satelit Oseanografi. Balai Penelitian dan Observasi Laut: Bali

Tawari, R.H.S. 2013. Efisiensi Jaring Insang Permukaan Terhadap Hasil Tangkapan Ikan Layang (Decapterus Macarelus) Di Teluk Kayeli. Jurnal "Amanisal" PSP FPIK Unpatti-Ambon. Vol. 2 (2) : 32- 39. 